\title{
ADDITIVES TO CONTROL THE QUALITY OF COFFEE HUSK POULTRY LITTER
}

Cecília de Fátima Souza ${ }^{1}$, Cláudia Ribeiro dos Santos $^{2}$, Keles Regina Antony Inoue ${ }^{3}$, Ilda de Fátima Ferreira Tinôco ${ }^{4}$ \& Williams Pinto Marques Ferreira ${ }^{5}$

1 - Agricultural Engineer, Professor, UFV/Viçosa-MG, Brasil, cfssouza@ufv.br.

2 - Agronomist, Researcher, IMA/Carangola- MG, Brasil.

3 - Agronomic Engineer, Post doctoral, UFRR

4 - Agricultural Engineer, Professor, UFV/Viçosa-MG, Brasil

5 - Meteorologist, Researcher, EMBRAPA-CNPC/Brasília-DF, Brasil.

\section{Keywords:}

poultry production

coffee production

organic compound

chemical conditioners

$\mathrm{N}$-ammonia

\section{ABSTRACT}

The poultry litter keeps the birds comfortable and absorbs the humidity generated in the environment, reducing the feet injuries. Then, its quality is essential. The objective for carrying out the present study was to evaluate the quality of the coffee husk poultry litter, treated with chemical additives, based on its humidity, $\mathrm{N}$-ammonia, $\mathrm{pH}$ and bacteria total counting. The experiment was carried out in Minas Gerais state, Brazil, in a coffee producer region. It were used three facilities, in which it were placed circular boxes, each of them divided in seven parts, $2 \mathrm{~m}^{2}$ each one, where it were put the different types of poultry litter, being these the seven treatments: sawdust and coffee husks litter, being this last, new and untreated or treated with different additives and reused. Twenty-two chicks were distributed in each treatment (154 birds per facility, 11 birds $\mathrm{m}^{-2}$ ). Litter samples were collected at 7, 21 and 42 days of birds age. The experimental design was in randomized blocks, subdivided plots. The results were submitted to ANOVA and Tukey's test. The hydrated lime increased the $\mathrm{pH}$ in the initial phase (7 days) and decreased the moisture of the reused litter, compared to the new one. The gypsum reduced the $\mathrm{pH}$ of the litter at the end of the second phase. The $\mathrm{N}$-ammonia content of the reused litter, without treatment, was superior compared to the new one, untreated and treated with lime. There was no effect on the standard counting of bacteria and on the surface temperature of the litter. Then, the use of chemical additives in the poultry litter constitutes a good strategy to control its quality, as well as the environmental conditions to produce poultry meat.

\section{Palavras-chave:}

avicultura

cafeicultura

composto orgânico

condicionadores químicos

N-amônia

\section{ADITIVOS PARA CONTROLE DA QUALIDADE DA CAMA DE FRANGO DE CASCA DE CAFÉ \\ RESUMO}

A cama de frango mantém as aves confortáveis e absorve a umidade gerada no ambiente, reduzindo assim as injúrias nos pés. Por conseguinte, a qualidade da cama de frango é essencial. O objetivo para realização do presente estudo foi avaliar a qualidade da cama de frango composta a partir de cascas de café, tratada com aditivos químicos. Esta avaliação foi baseada em sua umidade, concentração de $\mathrm{N}$-amônia, $\mathrm{pH}$ e contagem bacteriana total. O experimento foi conduzido no estado de Minas Gerais, Brasil, em uma região produtora de café. Foram utilizadas três instalações, nas quais foram instalados boxes circulares, cada um deles dividido em sete partes, de $2 \mathrm{~m}^{2}$ cada, onde foram colocados os diferentes tipos de cama aviária, correspondendo estas aos sete tratamentos experimentais: casca de café, nova e não tratada; casca de café, nova e tratada com superfosfato simples (30 kg t-1); casca de café, nova e tratada com gesso agrícola ( $40 \%$ do peso total); casca de café, nova e tratada com cal $(0,5 \mathrm{~kg}$ $\mathrm{m}-2$ ); casca de café, reutilizada (2 lotes); e serragem. Vinte e dois pintinhos foram distribuídos em cada tratamento, perfazendo um total de 154 aves por instalação, a uma densidade de 11 aves $\mathrm{m}^{-2}$. Foram coletadas amostras das várias camas aos 7,21 e 42 dias de idade das aves. O desenho experimental foi em blocos casualizados, parcelas subdivididas. Os resultados foram submetidos à ANOVA e ao teste de Tukey. A cal hidratada proporcionou um aumento do $\mathrm{pH}$ na fase inicial do ciclo de produção (7 dias), bem como uma diminuição da umidade na cama reutilizada, em comparação com a nova. $\mathrm{O}$ gesso reduziu o pH da cama no final da segunda fase do ciclo de produção. O teor de $\mathrm{N}$-amônia cama reutilizada sem tratamento foi maior em relação à nova, não tratada e tratada com cal. Não houve efeito de condicionadores químicos na contagem bacteriana e na temperatura da superfície da cama. Dessa forma, o uso de condicionadores químicos aplicados à cama de frango constitui uma boa estratégia para o controle de sua qualidade e das condições ambientais para a produção de frangos de corte. 


\section{INTRODUCTION}

Around the world, the most adopted system to raise chickens for meat has been the bedding. Recently, concerns about the welfare led researchers to focus attention, among others, on raising poultry in a litter of good quality, specifically with low humidity. To pay attention on this it is a way to assure welfare to these animals, referring to its right to be free to show behavioral patterns related to the aviary litter (SHEPHERD \& FAIRCHILD, 2010). Another concern, is the reduction of the concentration of pathogens in the litter in order to prevent diseases (FIORENTIN, 2006; FRASER et al., 2013). In addition, the control of the level of bacteria in the litter and the reduction in ammonia emission are also first-rate cares for offering to the animals a suitable environment (BOLAN et al., 2010; ZAPATA MARIN et al., 2015).

The litter for aviaries must have the function of thermal insulation, moisture absorption, dilution of urates and feces (KIM \& AGBLEVOR, 2007; ÁVILA et al., 2008), must provide comfort to the birds, allowing the expression of all its genetic potential and finally, the rate of injuries in the chest, knee and feet, caused by such litter, must be minimized (SIRRI et al., 2007; CENGIZ et al., 2011; ABREU \& ABREU, 2011). The suitable material for this purpose, must meet certain characteristics such as thermal insulation, average particle size, softness, absorbency and, at the same time, facility to release moisture, low cost and be easily obtained (BERNHART \& FASINA, 2009; CARVALHO et al., 2011). Dalólio et al. (2017) state that it is too important consider how far the source of this litter material is far from the farm that will use it, in order to reduce the costs of transportation.

When chickens are living in an environment, the $\mathrm{pH}$ ranges from 6 to 9 , the air humidity must vary around $65 \%$ and the air temperatures range from 20 to $32{ }^{\circ} \mathrm{C}$ depending on the age of the birds (AVILA et al., 2008). Due its composition, the litter is a great niche for bacteria to multiply, which is inevitable (DAI PRA et al., 2009; FRASER et al., 2013). Half of the nitrogen in poultry litter is lost as ammonia due to this microbial activity (BOLAN et al., 2010; MENDES et al., 2012). In addition, the ammonia concentration increases with the increasing in $\mathrm{pH}$ and its releasing reduces when $\mathrm{pH}$ is under 7 , but increases when above 8 , being the decomposition of uric acid favored at alkaline conditions (ZAPATA MARIN et al., 2015). Broiler chickens have been shown to avoid ammonia at $20 \mathrm{ppm}$ and higher, even if they have been exposed to such concentrations for most of their lives (FRASER et al., 2013).

According to some results of recent researches, the reduction in the moisture content improved the litter quality by decreasing the volatilization of ammonia and changing the $\mathrm{pH}$ (ZAPATA MARIN et al., 2015). When added to the litter, some substances act as conditioners. In the past, some investigation was carried out, concerning to apply chemical amendments (agricultural gypsum, aluminum sulfate, calcium oxide and simple superphosphate) to the litter in order to minimize the ammonia volatilization (GLORIA et al., 1991; MOORE et al., 2000; PROCHONOW et al., 2001).

The effect of addition of these substances on poultry litter can be explained by their action over this biological system, reducing the activity of bacteria and fungi (FERREIRA et al., 2004). As a consequence of that, may be reduced the ammonia production or be decreased its volatilization (FRASER et al., 2013; ZAPATA MARIN et al., 2015).

Mussato et al. (2011) mention that coffee has been consumed for over 1,000 years and today it is the most consumed drink in the world (more than 400 billion cups yearly). Minas Gerais state is the main Brazilian coffee producer, having produced in the last four years, an average of 24,5 bags per hectare (CONAB, 2014). Zona da Mata is the main producer in the Minas Gerais state, counting an estimated average for 2017 of 26 bags produced per hectare (CONAB, 2017). Residues from the coffee production units, like wastewater from processing and husks, may really be an environmental problem, if incorrectly discharged. The amount of husks may reach $50 \%$ of the total of harvested coffee (MUSSATO et al., 2011). One of the most used way to add value in this process is to apply the husks as bedding for animals.

In accordance with the exposed, this work was 
carried out aiming to evaluate the quality of the poultry litter of coffee husk, treated with chemical additives, taking into account the importance in using coffee husk in bedding systems for poultry production in Brazil due to its high availability in some specific regions.

\section{MATERIAL AND METHODS}

\section{Local}

The study was carried out during the winter in Brazil, in a poultry farm in Vicosa city, located in "Zona da Mata" of Minas Gerais state, considered an important region in coffee production. The local of this experiment is at $718 \mathrm{~m}$ altitude, latitude 20 o 41 ' 09 ' South and longitude $42^{\circ}$ 37' 11 West. The climate according to Köppen, is Cwa (warm temperate rainy, with a dry winter and hot summer).

\section{Facilities}

It were used three similar poultry facilities in the same productive site, positioned side by side and oriented from East to West. The three facilities have $14 \mathrm{~m}$ wide, $55 \mathrm{~m}$ long and $2.9 \mathrm{~m}$ of height. They were apart one from another, approximately in $8 \mathrm{~m}$. The roof was composed of clay tiles, eaves of $0.65 \mathrm{~m}$, without ridge vent. The ceiling lining was made of yellow polyethylene installed $2.9 \mathrm{~m}$ from the floor. The north and south faces of the buildings had walls of masonry (concrete blocks) with $0.3 \mathrm{~m}$ height, above which were attached wire mesh until the height of the ceiling lining. The curtains of yellow polyethylene had manual moving, pulling it down to open and pulling it up to close. These poultry houses were equipped with positive ventilation, with fans positioned in its laterals, as well as with evaporative cooling system.

\section{Experimental Features}

Within each facility it was placed a circular boxing divided in seven parts, each one of $2 \mathrm{~m}^{2}$ in area, corresponding such parts, to seven treatments (Figure 1A). The circular shape was adopted to guarantee a homogeneous distribution of heat to the birds, considering that in the center of each boxing was installed a gas heater (Figure 1B). The heating process was kept during the first 21 days of life of the birds.

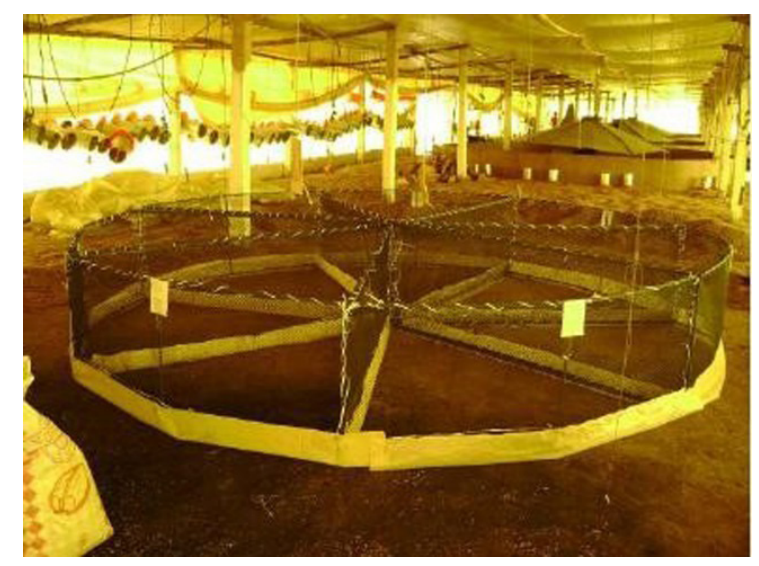

(A)

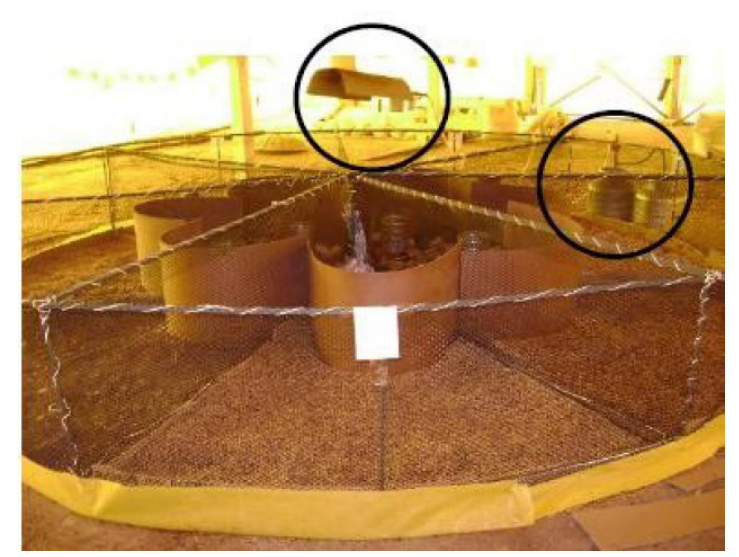

(B)

Figure 1. Circular boxing divided into seven parts corresponding to the treatments (A), detail of the heater in the center of the circle and the bottles of gas, outside the circle (B)

In the initial stage of the heating process, the chicks were confined in an area corresponding to one-third of the total area of each circle, called growth areas. These areas were separated by partition walls of pressed wood. As the chicks have been growing, it was increased this area up to 2 $\mathrm{m}^{2}$, at the end of 21 days of life of them, which was kept until 42 days of life, according to the management adopted by the producer.

Each boxing was equipped with appropriate feeders, like the "trays" and "tubular- type" and drinkers, like the "pressure cups" or "push fit 
chick drinkers", which were different from those normally used in the second stage of the production cycle, the pendulum-types.

Thus, each part of the boxing received a treatment (1 to 7), as following: $(\mathrm{CN})$ new poultry litter of coffee husk without treatment; $(\mathrm{CN}+$ SS) new poultry litter of coffee husk treated with superphosphate $\left(30 \mathrm{~kg} \cdot \mathrm{ton}^{-1}\right) ;(\mathrm{CN}+$ gypsum $)$ new poultry litter of coffee husk treated with agricultural gypsum at a proportion of $40 \%$ of the total weight of the litter; $(\mathrm{CN}+$ lime $)$ new poultry litter of coffee husk treated with lime $\left(0.5 \mathrm{~kg} . \mathrm{m}^{-}\right.$ $\left.{ }^{2}\right)$; (CR) coffee husk poultry litter reused from two lots; $(\mathrm{CR}+$ lime $)$ coffee husk poultry litter reused and treated with lime $\left(0.5 \mathrm{~kg} \mathrm{~m}^{-2}\right)$ and $(\mathrm{CM})$ new poultry litter of wood shavings (Figure 2). The application of such additives, in amounts indicated by Oliveira (2004), was made in the eve, before the distribution of the birds in the boxes, just by mixing them and revolving the litter, manually. In all of those treatments the litter was $6 \mathrm{~cm}$ thick. In the treatments "CR" and " $\mathrm{CR}+$ lime" it was applied a poultry litter previously used in two consecutive lots, being those before submitted to the fermentation process in covered piles to reduce the microbial load. All the conditioners were thoroughly mixed to the poultry litters.



(A)

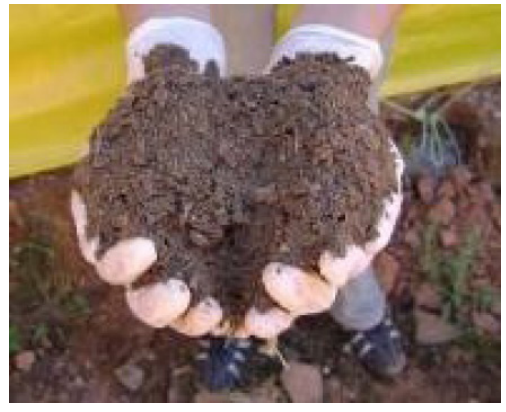

(B)

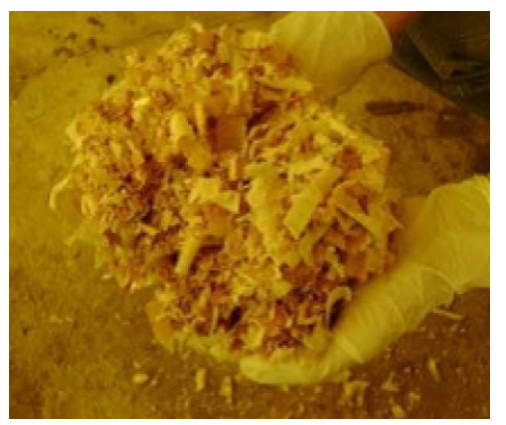

(C)

Figure 2. Materials used as poultry litter: coffee husk (A): reused litter of coffee husk (two lots) (B), wood shavings (C)

\section{Animals}

Twenty-two chicks, Ross lineage, males, were distributed in each treatment, totaling in each facility 154 birds, which were raised until 42 days of age.

\section{Litter Management and Sampling}

After filling all the parts in each boxing, the thick of the poultry litter before the housing of the birds it was measured. After that, weekly, the thickness and quality of each type of poultry litter were measured and recorded. And, after that, each one of the seven types of poultry litter was mixed up.

The quality of each material, based on the moisture content, $\mathrm{pH}$, ammonia-N and total counting of bacteria, was measured from samples collected in six random sites inside the boxing, at the beginning, middle and end of the experimental period, avoiding some points under the feeders and drinkers. These analyses were carried out in the Water Quality Laboratory, Agricultural Engineering Department, Federal University of Viçosa, according to Apha (2005) protocols. Samples of these same materials were also sent to Unit for Studies on Avian Health, Department of Veterinary, Federal University of Viçosa, in order to carry the standard counting of total bacteria, expressed as CFU (colony forming unit), by means the Plate Count Agar Method, as described by Depner et al. (2016), and in accordance with the IN 62 of the Brazilian Ministry of Agriculture (BRASIL, 2003).

Every day in the morning, afternoon and night ( 9 a.m., 3 p.m. and 9 p.m.) the temperature of the surface of the poultry litter at three different points in each treatment was measured, by means of an infrared sensor. Similarly, the air temperature at the level of the birds $(30 \mathrm{~cm}$ height from the litter 
surface) was obtained by means of sensors coupled to a temperature and humidity data acquisition system.

\section{Statistical Procedures}

The experimental design was in randomized blocks. To study the variable $\mathrm{N}$-ammonia, $\mathrm{pH}$, moisture and standard counting of total bacteria, that correspond to the characteristics of the poultry litter, it was used the subdivided plots, being the treatments the plot factors $(\mathrm{CN}, \mathrm{CN}+\mathrm{SS}, \mathrm{CN}+$ gypsum, lime $+\mathrm{CN}, \mathrm{CR}, \mathrm{CR}+$ lime and $\mathrm{CM})$. The period (before the housing of the birds, at 7, 21 and 42 days after) was the sub-plot factor. For the litter temperature, the same experimental scheme was applied. The difference was related to periods, which were designated as the six weeks in which it was carried out the experiment.

For all analyzes mentioned, it was used the F-test (ANOVA). The averages were compared by the Tukey test, $5 \%$ level of probability.

\section{RESULTS AND DISCUSSION}

From ANOVA for moisture content, $\mathrm{pH}$ and ammonia-N, it were identified differences ( $P$
$<0.05)$ between the treatments, but there was no effect of these treatments $(\mathrm{P}>0.05)$ on the standard counting of total bacteria.

The mean values for moisture content, ammonia-N and, the standard counting of total bacteria in the litter, under the effect of the different treatments are presented in Table 1.

It was observed effect $(\mathrm{P}<0.05)$ of the hydrated lime, but not of the other chemical conditioners on the moisture content of the reused coffee husk poultry litter. The new wood shavings poultry litter (CM), similar to the new coffee husk poultry litter $(\mathrm{CN})$, showed the highest moisture content (39.64\%) when compared to the reused litter treated with lime (CR + lime), Table 1 .

The results for moisture content in the litter, as presented in Table 1, firstly can be attributed to the age of the litter or by the fact the litter be reused. The new litter normally is more able to absorb and keep the moisture. Reused or old litter may present components more stabilized, sedimented or emplastered, that difficult the absorption of water. Particle size of the litter is another important factor affecting the moisture content, as it affects specific surface area, altering the absorption routes. Normally, if less absorbed by the litter, the

Table 1. Mean values of Moisture content (\%), N-ammonia $\left(\mathrm{g} \mathrm{kg}^{-1}\right)$ and Standard counting total bacteria $\left(\mathrm{CFU} \mathrm{\textrm {g } ^ { - 1 }}\right)$ the litter under different additions (treatments): $(\mathrm{CN})$ new poultry litter of coffee husk without addition; $(\mathrm{CN}+\mathrm{SS})$ new poultry litter of coffee husk treated with superphosphate; $(\mathrm{CN}+$ gypsum) new poultry litter of coffee husk treated with agricultural gypsum; $(\mathrm{CN}+$ lime $)$ new poultry litter of coffee husk treated with lime; $(\mathrm{CR})$ coffee husk poultry litter reused from two lots; $(\mathrm{CR}+$ lime $)$ coffee husk poultry litter reused and treated with lime and (CM) new poultry litter of wood shavings

\begin{tabular}{ccccccc}
\hline Treatments & \multicolumn{2}{c}{$\begin{array}{c}\text { Moisture content } \\
(\%)\end{array}$} & \multicolumn{2}{c}{$\begin{array}{c}\text { N-ammonia } \\
\left(\mathrm{g} \mathrm{kg}^{-1}\right)\end{array}$} & $\begin{array}{c}\text { Standard counting } \\
\text { total bacteria } \\
\left(\mathrm{CFU} \mathrm{g}^{-1}\right)\end{array}$ \\
\hline $\mathrm{CN}$ & 38.04 & $\mathrm{a}$ & 4.19 & $\mathrm{~b}$ & $1.04 \times 10^{12}$ & $\mathrm{a}$ \\
$\mathrm{CN}+\mathrm{SS}$ & 34.10 & $\mathrm{ba}$ & 4.94 & $\mathrm{ba}$ & $0.75 \times 10^{12}$ & $\mathrm{a}$ \\
$\mathrm{CN}+$ gypsum & 31.94 & $\mathrm{ba}$ & 4.85 & $\mathrm{ba}$ & $1.10 \times 10^{12}$ & $\mathrm{a}$ \\
$\mathrm{CN}+$ lime & 34.55 & $\mathrm{ba}$ & 3.94 & $\mathrm{~b}$ & $1.31 \times 10^{12}$ & $\mathrm{a}$ \\
$\mathrm{CR}$ & 29.61 & $\mathrm{ba}$ & 6.46 & $\mathrm{a}$ & $1.15 \times 10^{12}$ & $\mathrm{a}$ \\
$\mathrm{CR}+$ lime & 27.47 & $\mathrm{~b}$ & 5.48 & $\mathrm{ba}$ & $0.86 \times 10^{12}$ & $\mathrm{a}$ \\
$\mathrm{CM}$ & 39.64 & $\mathrm{a}$ & 4.83 & $\mathrm{ba}$ & $1.32 \times 10^{12}$ & $\mathrm{a}$ \\
\hline
\end{tabular}

Means followed by at least one letter in the column, do not differ, at $5 \%$ probability by the Tukey test. 
water may deposit on its surface, being easier the spreading to the immediate environment, which may be not desirable. Finally, add substances to the litter will surely alter its ability for retention of moisture, which is also affected, among others, by the particle size of those compounds.

Oliveira et al. (2004) observed no effect (P> 0.05 ) of chemical conditioners such as aluminum sulfate, gypsum, superphosphate and lime on the dry matter content in a poultry litter of wood shavings. They also observed no difference in moisture content $(\mathrm{P}>0.05)$ on a new poultry litter of wood shavings $(35.58 \%)$ and a reused one $(42.16 \%)$, treated or not with different additives (superphosphate, agricultural gypsum and lime).

Some authors, like Santos et al. (2005), refer to the importance to consider aspects like the absorption capacity of the materials, the thick adopted for the poultry litter and the density of occupation, i.e., the number of animals per area unit. Dalólio et al. (2017) also mention that the importance of the quality of the diet of the birds influences the quality of the litter. There are food additives that reduce the discharge of bacteria and pathogens and, in addition, the formulation of diets with an ideal protein concept and the use of enzymes in the diet reduces the excretion of water, $\mathrm{N}$ and $\mathrm{P}$ in the litter. All these details can influence the moisture content. In the present study it was used $6 \mathrm{~cm}$ thick in the litter and 11 birds $\mathrm{m}^{-2}$ density. In normal density $\left(10\right.$ birds $\left.\mathrm{m}^{-2}\right)$, Oliveira et al. (2004) observed moisture content of 34.92 and $36.88 \%$ in litter of wood shavings and of sawdust, respectively. They concluded that the ideal material should be able to release and does not retain moisture, in the way it can be spread to the environment and eliminated by ventilation.

The litter should be managed so that its moisture is between $20 \%$ and $35 \%$, because in moisture contents above those, the litter becomes plastered. Adequate facilities, curtains and management of ventilation are essential items to maintain the quality of the litter, especially during critical weather (AVILA et al., 2008).

There was no effect $(\mathrm{P}>0.05)$ of treatments on the standard counting of total bacteria (Table 1). Although similar to other treatments $(\mathrm{P}>0.05)$, the lowest value was found in the new litter treated with superphosphate, $0.75 \times 10^{12} \mathrm{CFU} \mathrm{g}^{-1}$, coinciding with the treatment with one of the lowest initial value for $\mathrm{pH}$ (5.69). It is possible that the acidity has inhibited the proliferation of bacteria and the formation of ammonium compounds in the medium, as mentioned by Santos et al., 2012. Another record for low bacterial counting can be observed in the reused litter, treated with lime, which is also in accordance with these same authors. The litter of wood shavings showed the highest value, $1.32 \times 10^{12} \mathrm{CFU} \mathrm{g}^{-1}$, which coincides, however, with the treatment of highest moisture content (39.64\%). Vieira et al. (2015), when studying the sanitary quality of broiler litter, mention that an increase of $1 \%$ in the moisture content generates an increase of 11.25 percentage points in the probability of occurrence of Salmonella spp in the coffee husk litter.

The presence of organic matter (manure, feed and animal remains) favors the growth of the microorganisms that decompose uric acid present in excreta, increasing the ammonia release, thus raising the $\mathrm{pH}$ of the poultry litter.

Still from the Table 1, there was significant difference $(\mathrm{P}<0.05)$ among the treatments, referring to the $\mathrm{N}$-ammonia on the litter. The reused litter presented the concentration of ammonia-N, $(6.46 \mathrm{~g}$ $\mathrm{kg}^{-1}$ ), greater than the new litter treated with lime, $\left(3.94 \mathrm{~g} \mathrm{~kg}^{-1}\right)$, and greater than the new litter without treatment, $\left(4.19 \mathrm{~g} \mathrm{~kg}^{-1}\right)$. It is possible that the use of the poultry litter for more than one lot can justify the higher concentration of $\mathrm{N}$-ammonia, since the amount of excretion deposited on the litter increases at every cycle of production, favoring the formation of ammonia compounds. According to Freitas et al. (2011), nitrogenous compounds, present in manures, are used in the physicalchemical and bacteriological processes that occur in the litter and may be related to the ammonia concentration.

Wheeler et al. (2006), studying ammonia emission from twelve U.S. broiler houses, found a regression slope of $0.031 \mathrm{~g}$ of ammonia emitted per bird per day, per each day of age. These same authors mention that the units of production managed with new litter had the lowest emission rate $(0.024 \mathrm{~g}$ of ammonia per bird per day. In the present work, it can be seen that, as wastes were accumulated in the reused litter, the ammonia concentration was increased. Other factors, like $\mathrm{pH}$ and temperature, also influence the ammonia concentration in the litter and its volatilization.

The mean values of $\mathrm{pH}$ for the different treatments, as observed before housing, and at 7 , 21 and 42 days of life of the birds, are presented in Table 2.

There was significant difference $(\mathrm{P}<0.05)$ 
between treatments on the $\mathrm{pH}$ of the litter. The $\mathrm{pH}$ of the new litter treated with lime ( $\mathrm{CN}+$ lime), (6.57), was slightly higher $(\mathrm{P}<0.05)$ than the new one without treatment (5.83) at 7 days of experiment. Although similar $(\mathrm{P}>0.05)$ to the control treatment $(\mathrm{CN})$, the $\mathrm{pH}$ of the new litter treated with gypsum (CN + gypsum), (5.66), and superphosphate $(\mathrm{CN}+$ SS), (5.69), was lower $(\mathrm{P}<0.05)$ than that observed in the reused litter (8.25) in the initial phase of the experiment (Table 2).

About the $\mathrm{pH}$, results similar to those presented in Table 2 were observed by Oliveira et al. (2004), whom reported that the $\mathrm{pH}$ of the poultry litter was not influenced by use of the normal superphosphate and gypsum. In the present work, at the end of the experiment (42 days), the new litter treated with gypsum had the lowest $\mathrm{pH}$ value (8.44).

Considering that the $\mathrm{pH}$ at the end of the experiment (42 days) was high, all treatments have produced ammonia, since, according to Logan \& Vos (2015), one of the major bacteria involved on the urea lysis, the Bacilius pasteurii, cannot grow at neutral $\mathrm{pH}$ values, but develop in $\mathrm{pH}$ values above those. It was expected that the superphosphate, being an acidic substance, would decrease the $\mathrm{pH}$ down until the end of the experiment. It can be inferred that this product may have lost the efficiency to maintain low $\mathrm{pH}$, as the time went on or the dosage has been low, or, maybe one more application of it, would be necessary in the last days of the cycle to attain this goal.

About the coffee husks, Carneiro et al. (2009) emphasize that this material has in its composition, significant amounts of cellulose, proteins and fibers. Machado (2009) states that this material is toxic and needs some actions to guarantee the detoxification, like use it as substrate in fermentative processes, in order to allow its disposition in the environment. Mussato et al. (2011) mention that by the conversion of cellulose to glucose, products like ethanol can be produced in fermentative processes, which reinforces the energy potential of this residue. In the other hand, the coffee husks exhibit a good antioxidant potential. But it seems these characteristics did not influence the $\mathrm{pH}$ variation in a significant way, when compared with the wood shavings. However, Carvalho et al. (2011), studying air quality in poultry facilities, found more acidified medium, $\mathrm{pH} 5.6$ in average, in closed facilities, equipped with litter of coffee husks, when compared to those with litter of wood shavings.

The average surface temperatures of the poultry litter are shown in Table 3.

There was no effect $(\mathrm{P}>0.05)$ of treatments on the surface temperature of the litter, except in the second and in the fifth week of birds life, respectively, in which there was a significant difference $(\mathrm{P}<0.05)$ between the reused litter, treated with lime and the reused one, no treated, that presented higher temperature than the other ones.

The average surface temperature of the litter in the first, third and in the fourth week of birds life, were similar to their comfort temperatures for these stages. However, the values of surface temperature of the litter at the end of the production period were higher than those considered appropriate for the welfare and

Table 2. Mean values of $\mathrm{pH}$ in the litter, before housing the birds, at 7,21 and 42 days of experiment, under different additions (treatments): $(\mathrm{CN})$ new litter of coffee husk without treatment; $(\mathrm{CN}+\mathrm{SS})$ new litter of coffee husk treated with superphosphate; $(\mathrm{CN}+$ gypsum $)$ new litter of coffee husk treated with agricultural gypsum; $(\mathrm{CN}+$ lime $)$ new litter of coffee husk treated with lime; $(\mathrm{CR})$ coffee husk litter reused from two lots; $(\mathrm{CR}+$ lime $)$ coffee husk litter, reused and treated with lime and (CM) new litter of wood shavings

\begin{tabular}{cccccccc}
\hline Treatments & $\begin{array}{c}\text { Before } \\
\text { housing }\end{array}$ & \multicolumn{2}{c}{ At 7 days } & At 21 days & \multicolumn{2}{c}{ At 42 days } \\
\hline CN & 7.77 & 5.83 & c & 4.19 & a & 9.11 & a \\
CN + SS & 5.25 & 5.69 & c & 4.94 & a & 9.15 & a \\
CN + gypsum & 5.15 & 5.66 & c & 4.85 & a & 8.44 & b \\
CN + lime & 7.73 & 6.57 & b & 3.94 & a & 8.88 & ba \\
CR & 8.40 & 8.25 & a & 6.46 & a & 9.14 & a \\
CR + lime & 9.77 & 8.24 & a & 5.48 & a & 8.97 & ba \\
CM & 5.22 & 6.57 & b & 4.83 & a & 9.22 & a \\
\hline
\end{tabular}

Means followed by at least one letter in the column, do not differ, at $5 \%$ probability by the Tukey test. 
Table 3. Mean surface temperature, in ${ }^{\circ} \mathrm{C}$, of the poultry litter in the different treatments, $(\mathrm{CN})$ new litter of coffee husk without treatment; $(\mathrm{CN}+\mathrm{SS})$ new litter of coffee husk treated with superphosphate; $(\mathrm{CN}+$ gypsum $)$ new litter of coffee husk treated with agricultural gypsum; $(\mathrm{CN}+$ lime $)$ new litter of coffee husk treated with lime; (CR) coffee husk litter reused from two lots; (CR + lime) coffee husk litter, reused and treated with lime and (CM) new litter of wood shavings

\begin{tabular}{|c|c|c|c|c|c|c|c|c|c|c|c|c|}
\hline \multirow{3}{*}{$\begin{array}{c}\text { Treatments } \\
\mathrm{CN}\end{array}$} & \multicolumn{12}{|c|}{ Weeks } \\
\hline & \multicolumn{2}{|c|}{1} & \multicolumn{2}{|c|}{2} & \multicolumn{2}{|c|}{3} & \multicolumn{2}{|c|}{4} & \multicolumn{2}{|c|}{5} & \multicolumn{2}{|c|}{6} \\
\hline & 31.2 & $\mathrm{a}$ & 27.6 & $\mathrm{ba}$ & 27.2 & $\mathrm{a}$ & 26.5 & $\mathrm{a}$ & 26.7 & ba & 27.9 & $\mathrm{a}$ \\
\hline $\mathrm{CN}+\mathrm{SS}$ & 31.4 & $\mathrm{a}$ & 27.7 & $\mathrm{ba}$ & 27.3 & $\mathrm{a}$ & 26.6 & $\mathrm{a}$ & 27.1 & ba & 28.2 & $\mathrm{a}$ \\
\hline $\mathrm{CN}+$ gypsum & 31.2 & $\mathrm{a}$ & 27.4 & ba & 27.1 & $\mathrm{a}$ & 26.6 & $\mathrm{a}$ & 26.6 & $\mathrm{ba}$ & 27.8 & $\mathrm{a}$ \\
\hline $\mathrm{CN}+$ lime & 30.7 & $\mathrm{a}$ & 27.1 & $\mathrm{~b}$ & 27.1 & $\mathrm{a}$ & 26.5 & $\mathrm{a}$ & 26.5 & $\mathrm{~b}$ & 27.7 & $\mathrm{a}$ \\
\hline CR & 32.1 & a & 27.9 & ba & 27.3 & $\mathrm{a}$ & 26.2 & $\mathrm{a}$ & 27.3 & $\mathrm{a}$ & 28.6 & $\mathrm{a}$ \\
\hline $\mathrm{CR}+$ lime & 21.1 & a & 28.7 & $\mathrm{a}$ & 27.2 & $\mathrm{a}$ & 26.4 & $\mathrm{a}$ & 27.2 & ba & 26.6 & $\mathrm{a}$ \\
\hline $\mathrm{CM}$ & 32.0 & $\mathrm{a}$ & 27.6 & ba & 26.6 & $\mathrm{a}$ & 26.7 & $\mathrm{a}$ & 26.8 & ba & 28.2 & $\mathrm{a}$ \\
\hline
\end{tabular}

Means followed by at least one letter in the column, do not differ, at $5 \%$ probability by the Tukey test.

Table 4. Average litter surface temperature, air temperature and comfort temperature for poultry, during the experimental weeks

\begin{tabular}{cccccccc}
\hline \multirow{2}{*}{ Temperatures } & \multicolumn{7}{c}{ Weeks } \\
\cline { 2 - 7 } & 1 & 2 & 3 & 4 & 5 & 6 \\
\hline T. Surface $\left({ }^{\circ} \mathrm{C}\right)$ & 31.5 & 27.7 & 27.1 & 26.6 & 26.9 & 28.1 \\
T. Air $\left({ }^{\circ} \mathrm{C}\right)$ & 25.3 & 24.4 & 24.2 & 23.2 & 21.3 & 22.0 \\
T.Comfort $\left({ }^{\circ} \mathrm{C}\right) *$ & $30-33$ & $29-31$ & $27-29$ & $25-26$ & $22-23$ & 21 \\
\hline
\end{tabular}

* Baêta \& Souza (2010); Abreu \& Abreu, (2011)

the good performance of the poultry at this stage, according to Baêta \& Souza (2010) and Abreu \& Abreu, (2011), as can be seem at the Table 4.

Related to the temperatures, as presented in Table 3, according to Oliveira (2004), in the bedding systems, it must be considered the heat generated by the binomial "animal plus litter". In the present work, however, the air temperature was too below the surface temperature of the litter (Table 4), which can be attributed, in part, to the ventilation and to the period of data collection, which was winter.

One of the functions of the litter, according to Paganini (2004), is to reduce the contact of the birds with a cold surface, which causes the loss of body heat to the floor. Shallow litter of inadequate materials allows thermal conductivity between the floor and the air, making it difficult to maintain a suitable temperature to birds (GARCIA \& CALDARA, 2011; FRASER et al., 2013).

\section{CONCLUSION}

- According to the results previously presented, it can be concluded that the use of chemical additives such as the superphosphate, agricultural gypsum and lime in the poultry litter of coffee husks constitutes a good strategy to control its quality, as well as to adjust the environmental conditions, facilitating to attain the animal welfare and, consequently better production, in this case, of poultry meat.

\section{ACKNOWLEDGEMENTS}

The authors thank the Federal University of Viçosa, for the great opportunity to carry out this work; to FAPEMIG (Brazilian State Government Agency), to $\mathrm{CNPq} / \mathrm{Brazil}$ (National Council of Technological and Scientific Development) and to CAPES/Brazil (Coordination for the Improvement of Higher Education Personnel).

\section{REFERENCES}

ABREU, P.G.; ABREU, V.M.N. The challenges of animal environment on the poultry systems in Brazil. Revista Brasileira de Zootecnia, v.40, p.114, 2011. 
American Public Health Association APHA, American Water Works Association AWWA, Water Environment Federation WEF. (2005). Standard methods for the examination of water and wastewater. 21 st ed., Washington.

ÁVILA, V.S.; OLIVEIRA, U.; FIGUEIREDO, E.A.P.; COSTA, C.A.F.; ABREU, V.M.N.; ROSA, P.S. Avaliação de materiais alternativos em substituição à maravalha como cama de aviário. Rev. Bras. Zootec., v.37, n.2, p.273-277. 2008.

BAETA, F.C., SOUZA, C.F. Ambiência em edificações rurais - conforto animal. (2nd ed). Vicosa, Editora-UFV, 269p. 2010

BERNHART, M.; FASINA, O.O. Moisture effect on the storage, handling and flow properties of poultry litter. Waste Management. v.29, n.4, p. 1392-1398. 2009. https://doi.org/10.1016/j. wasman.2008.09.005

BOLAN, N.S.; SZOGI, A.A., CHUASAVATHTI, T; SESHADRI, B.; ROTHROCK JR., M.J.; PANNEERSELVAM, P. Uses and management of poultry litter. Word's Poultry Science Journal, v.66, p. 673-698. 2010.

BRASIL. Ministério da Agricultura, Pecuária e Abastecimento. Instrução Normativa n. 62 de 26 de agosto de 2003. Métodos analíticos oficiais para análises microbiológicas para controle de produtos de origem animal e água. Diário Oficial da União, Brasília, DF, 2003.

CARNEIRO, L.M.; SILVA, J.P.A.; MUSSATTO, S.I.; ROBERTO, I.C.; TEIXEIRA, J.A. Determination of total carbohydrates content in coffee industry residues. In: 8th International Meeting of the Portuguese Carbohydrate Group, GLUPOR, pp 94, 6-10 September 2009, Braga, Portugal (Book of abstracts).

CARVALHO, T.M.R.; MOURA, D.J.; SOUZA, Z.M.; SOUZA, G.S.; BUENO, L.G.F. Qualidade da cama e do ar em diferentes condições de alojamento de frangos de corte. Pesq. Agropec. Bras., v.46, n.4, p. 351-361. 2011.

CENGIZ, O.; HESS, J.B.; BILIGILI, S.F. Effect of bedding type and trasient wetness on foot pad dermatitis in broiler chickens. Journal of Applied Poultry Research, v. 20 p. 554-560, 2011.

Companhia Nacional de Abastecimento - CONAB.
Acompanhamento da Safra Brasileira de Café, Safra, Quarto Levantamento, Brasília: Companhia Nacional de Abastecimento, 51p. 2014.

Companhia Nacional de Abastecimento - CONAB. Estimativa safra brasileira de Café 2017, Safra, Segundo Levantamento, Brasília: Companhia Nacional de Abastecimento, 40p. 2017

DEPNER, R.F.R.I.; PONTIN, K.P.I.; DEPNER, R.A.I.I.; FLORES NETO A.I.I.I.; LUCCA, V.I.; LOVATO, M.I. Action of Antimicrobial copper on bacteria and fungi isolated from commercial poultry hatcheries. Brazilian Journal of Poultry Science. v.2, p.95-98. 2016. http://dx.doi. org/10.1590/1806-9061-2016-0277

DAI PRA, M. A.; CORREA, E.K.; ROLL, V.F.; XAVIER, E.G.; LOPES, D.C.N.; LOURENÇO, F.F.; ZANUSSO, J.T.; ROLL, A. P. Uso de cal virgem para o controle de Salmonellaspp. e Clostridium spp. em camas de aviário. Ciência Rural, v. 39, n.4, p. 1189-1194, 2009.

DALOLIO, F.S.; SILVA, J.N.; OLIVEIRA, A.C.C.; TINOCO, I.F.F.; BARBOSA, R.C.; RESENDE, M.O; ALBINO, L.F.T.; COELHO, S.T. Poultry litter as biomass energy: A review and future perspectives. Renewable and Sustainable Energy Reviews, v. 76, p. 941-949, 2017. http:// dx.doi.org/10.1016/j.rser.2017.03.104

FREITAS,L.W.; GARCIA，R.G.; NÄÄS，I.A.; CALDARA, F.R.; LIMA, N.D.S. Volatilization of ammonia in different types of broiler litter. BioEng, v.5 n.3, p. 142-151, 2011.

FERREIRA, H.A.; OLIVEIRA, M.C.; TRALDI, A.B. Efeito de condicionadores químicos na cama de frango sobre o desempenho de frangos de corte. Arquivos Brasileiros de Medicina Veterinária e Zootecnia, v.56, n.4, p. 542-546, 2004. http:// dx.doi.org/10.1590/S0102-09352004000400017.

FIORENTIN, L. Aspectos bacteriológicos da reutilização da cama de aviário. Proceedings of Seminário Internacional de Aves e Suínos AveSui, Florianópolis, SC, Brasil. 2006

FRASER, D.; DUNCAN, I.J.H.; EDWARDS, S.A.; GRANDIN, T.; GREGORY, N.G.; GUYONNET, V.; HEMSWORTH, P.H.; HUERTAS, S.M.; HUZZEY, J.M.; MELLOR, D.J.; MENCH, J.A.; ŠPINKA, M.; WHAY, H.R. General Principles for the welfare of animals in production systems: The underlying science and its 
application. Veterinary Journal, v.198, p.19-27, 2013. http://dx.doi.org/10.1016/j.tvj1.2013.06.028

GARCIA, R.G.; PAZ, I.; CALDARA, F.R. Papel da cama na produção e bem estar de frangos de corte. Revista Avisite, v.47, p.46-50, 2011.

GLÓRIA, N.A.; BARRETO, M.C.V.; MORAES, C.J. et al. Avaliação do gesso e de alguns fosfatos como inibidores da volatilização de amônia de estercos. Revista Brasileira de Ciência do Solo, v.15, n.3, p.297-301, 1991.

KIM, S.; AGBLEVOR, F.A. Pyrolysis characteristics and kinectics of chicken litter. Waste Management, v.27, p. 135-140. Elsevier, 2007.

LOGAN, N. A.; VOS, P.D. Bacillus. Bergey's Manual of Systematics of Archaea and Bacteria. John Wiley \& Sons, Inc. p.1-163. 2015. doi: 10.1002/9781118960608.gbm00530

MACHADO, E.S.M. Reaproveitamento de resíduos da indústria do café como matéria-prima para a produção de etanol. MSc thesis, Department of Biological Engineering, University of Minho, Braga, Portugal. 2009.

MENDES, L.B.; TINÔCO, I.F.F.; SOUZA, C.F.; SARAZ, J.A.O. O ciclo do nitrogênio na criação de frangos de corte e suas perdas na forma de amônia volátil; uma revisão. Pubvet, v.6, n.20, art. 1383. 2012.

MOORE, P.A., DANIEL, T.C., EDWARDS, D.R. (). Reducing phosphorus runoff and inhibiting ammonia loss poultry manure with aluminum sulfate. Journal of Environmental Quality, v.1, n.29, p. 29-37, 2000. doi:10.2134/ jeq2000.00472425002900010006x

MUSSATO, S.I.; MACHADO, E.M.S.; MARTINS, S.; TEIXEIRA, J.A. Production, composition, and application of coffee and its industrial residues. Food Bioprocess Technol. v.4, p. 661-672. 2011. doi: 10.1007/s11947-011-0565-Z

OLIVEIRA, M.C.; FERREIRA, H.A.; CANCHERINI, L.C. Effect of chemical conditioners on poultry litter quality. Arq. Bras. Med. Vet. Zootec., v.56, n.4, p.536-541, 2004. doi: 10.1590/S0102-09352004000400016

PAGANINI, F.J.. Manejo da cama. In: MENDES, A., NÄÄS, I.A., MACARI, M. Produção de frangos de corte. Campinas: Facta, p. 107-116, 2004.

PROCHONOW, L.I. CUNHA, C.F., KIEHL, J.C. Controle da volatilização de amônia em compostagem, mediante adição de gesso agrícola e superfosfato com diferentes níveis de acidez residual. Revista Brasileira de Ciência do Solo. v. 25 , p. 65-70. 2001.

SANTOS, T.M.B., LUCAS JR, J., SAKOMURA, N.K. Efeitos da densidade populacional e da reutilização da cama sobre o desempenho de frangos de corte e produção de cama. Revista Portuguesa de Ciências Veterinárias, 100(553554), p. 45-52. 2005.

SANTOS, M.J.B.;SAMAY, A.M.A.T.; SILVA, D.A.T.; RABELLO, C.B.; TORRES, T.R.; SANTOS, P.A.; CAMELO, L.C.L. Manejo e tratamento de cama durante a criação de aves. Revista Eletrônica Nutritime. v.9, n.3. 2012.

SHEPHERD, E.M., FAIRCHILD, B.D. Footpad dermatitis in poultry. Poultry Science, v. 89, n.10, p. 2043-2051, 2010. doi: 10.3382/ps.2010-00770

SIRRI, F.;MINELLI, E..; FOLEGATTI,E.; LOLLI,S.; MELUZZI, A. Foot dermatitis and productive traits in broiler chickens kept with different stocking densities, litter types and light regimen. Ital.J.Anim.Sci., v.6 (suppl.1), p.734736. 2007.

VIEIRA, M.F.A.; TINOCO, I.F.F.; SANTOS, B.M.; INOUE, K.R.A.; MENDES, M.A.S.A.; Sanitary quality of broiler litter reused. Eng. Agríc.,v.35, n.5, p. 800-807, 2015. http:// dx.doi.org/10.1590/1809-4430-Eng.Agric. v35n5p800-807/2015

WHEELER, E.F.; CASEY, K.D.; GATES, R.S.; XIN, H.; ZAJACZKOWSKI, J.S.; TOPPER, P.A.; LIANG, Y.; PESCATORE, A.J. Ammonia emissions from twelve U.S. broiler chicken houses. Transactions of the ASAE, v.49, n.5, p. 14951512. 2006.

ZAPATA MARIN, O.L., TINOCO, I.F.F., SARAZ, J.A.O., SOUZA, C.F., VIEIRA, M.F.A. Evaluation of the fertilizer and contamination potential of different broiler litter types subjected to various use cycles. Rev. Fac. Nal. Agr., 68(2),7637-7646, 2015. doi: 10.15446/rfnam. v68n2.50967 